\title{
PERCEPTION AND ECONOMICS OF DRY DIRECT SEEDED RICE IN TERAI OF NEPAL
}

\author{
M. Dhakal, ${ }^{1}$ Shrawan K. Sah ${ }^{2}$, Andrew McDonald ${ }^{3}$, and Anant P. Regmi ${ }^{4}$
}

\begin{abstract}
Transplanting is widely practiced methods of rice establishment in puddled soils require large amount of labor and water, which are becoming scarce and expensive in Nepal. A field survey was carried out in six districts of terai region of Nepal during 2010. Sixty farmers, ten from each district were randomly selected. They were interviewed using face-to-face method based on semi-structured questionnaires to know their perception towards constraints, and economics of dry direct seeded rice (DDSR). Farmers were mostly using transplanted rice (TPR) because of less weed infestation and better crop establishment, but they were concerned with high cost of cultivation, higher water requirement and deterioration of soil after puddling operation. Farmers perceived DDSR as a cost reducing and less water requiring technology whereas severe weed infestation, poor crop establishment and reduced grain and straw yield were the major nuisance. Nevertheless, the B:C ratio of DDSR (2.0) was found higher than TPR (1.63). Therefore, DDSR could be an alternative to TPR in reducing cost of cultivation; however weeds are serious problems.
\end{abstract}

Key words: cost, dry direct seeded rice, productivity, transplanted rice, weed management

\section{INTRODUCTION}

Rice (Oryza sativa L. var. Indica) is the staple food of about half of the world's population, the majority of which is located in Asia (Palis et al., 2010). In Nepal, rice is commonly planted by transplanting seedlings of 20-25 days on puddled soil. However, transplanting is becoming increasingly difficult due to shortage and high cost of labour, scarcity of water, loss of soil physical properties and increase in cost of cultivation (Rao, 2010). Whereas DDSR is becoming popular as it is cheaper alternative to transplanting. The direct-seeded area in Asia is about 29 million ha, which is approximately $21 \%$ of the total rice area in the region (Pandey and Velasco, 1999). Dry seeding saves labor at transplanting, provide faster and easier crop establishment. It involves less drudgery, provides additional benefit in raising the crop through saving $29 \%$ of total cost of production of the transplanted rice (Ho, 1998). DDSR reduces the irrigation requirement by $30 \%$ of the total water $(1400-1800 \mathrm{~mm})$ required for rice culture (Gopal et al., 2010), and have a high tolerance of water deficit (Yadav et al., 2004). Direct seeding of rice also allows early establishment of the wheat crop because rice crop mature 7-10 days earlier than transplanted crops (Balasubramanian

\footnotetext{
${ }^{1}$ Agriculture officer, Gov. of Nepal, National Agricultural Research and Development Fund (NARDF), Nepal;

${ }^{2}$ Curriculum director, Agriculture and Forestry Univ., Nepal;

${ }^{3}$ International Maize and Wheat Improvement Center (CIMMYT), Kathmandu, Nepal;

${ }^{4}$ Cereal System Initiative for South Asia (CSISA), Nepal. ; Corresponding author (email: madhavdhakal23@gmail.com).
} 
and Hill, 2002). Yield in DDSR is often lower than TPR principally owing to poor crop stand and high weed infestation (Singh et al., 2005).

Generally, water availability and the opportunity cost of labor are the major determinants of DDSR adoption. Dynamic labour markets are increasing in Nepal, though foreign labour markets attracted most of the Nepalese youths. Therefore, the transplanting method, although effective in controlling weeds, may not be feasible when labour is scarce and water availability for establishment is low or uncertain. In order to save water and labor and promote conservation agriculture (CA), with no/reduced tillage, it is absolutely essential to replace TPR with DDSR (Mann et al., 2007). It was felt necessary to assess farmer's perception towards DDSR over TPR with respect to its economics, constraints, and the choice of suitable weed management technology by the farmers in three clusters of CSISA (Cereal System Initiative for South Asia) project.

\section{MATERIALS AND METHODS}

In 2010, sixty DSR growing farmers, twenty from each cluster were randomly selected from the master list of farmers of CSISA project who adopted the technology in the previous year (In 2009). First cluster include Bara and Parsa districts (B/P), second Chitwan and Makwanpur $(C / M)$ districts of central terai region, and third include Nawalparasi and Rupandehi (N/R) districts of western terai region of Nepal (Figure 1).

The region under study was very important in terms of trade and commerce along with modern agricultural technology. Rice, wheat and maize were the major cereals grown in these districts. Direct seeding of rice was practiced traditionally in Parsa, Bara, and

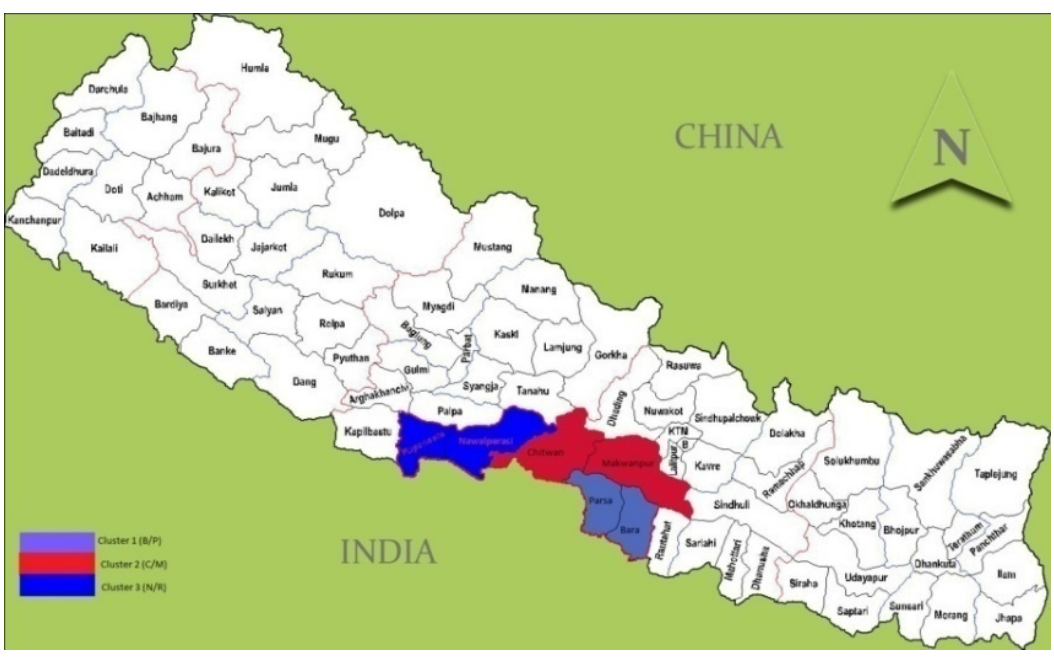

Figure 1: Map of Nepal showing study area under CSISA project during 2010.

Rupandehi districts by some ethnic groups like Tharu.

Survey was conducted using of face-to-face interview method based on semi-structured questionnaires constituted general demographics, assess to resource, cropping system, perceptions of direct seeding in rice, perception of relative damage to crop yield caused by 
different weeds, use of herbicides to control weeds, and cost and return of direct seeded and transplanted rice. Farmer's perception to constraints and advantages of DDSR and TPR were ranked by using five point scales of variables comprising most, relatively more, moderate, modest, and not at all, using scores of 1.00, 0.75, 0.50, 0.25, and 0.00, respectively. The priority index for each variable was calculated by using formula of Miah (1993).

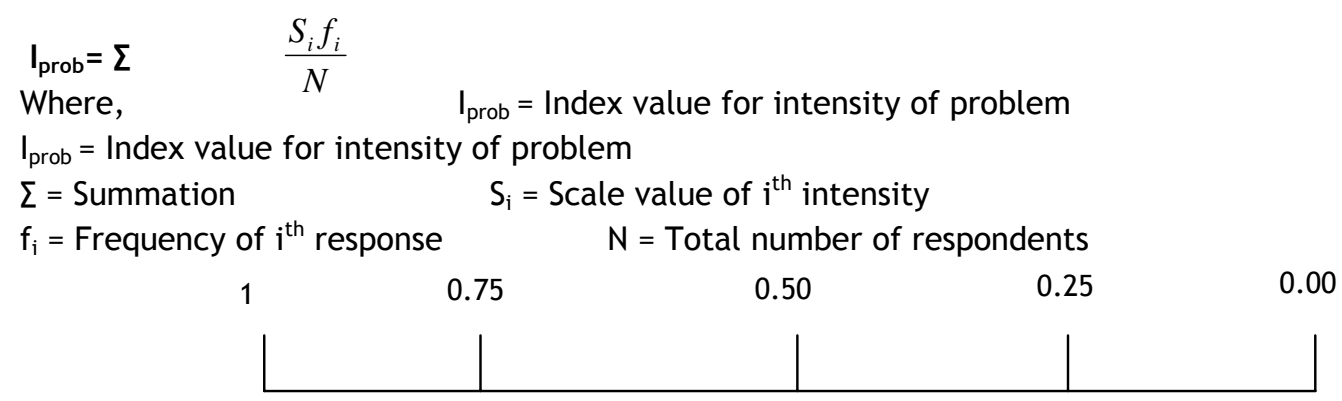

Figure 2: Scale value for intensity of constraints and advantages by farmers in cluster area of CSISA

The information collected from the field was analyzed by using computer software package i.e. Statistical Package for Social Science (SPSS) and Microsoft Excel.

\section{RESULTS AND DISCUSSION}

\section{I) LAND HOLDING OF FARMERS}

Most of the households in the clusters were small land holders i.e. less than 2 ha $(60 \%)$ (Figure 3). Besides cultivation their own land, farmers were found to be involved in share cropping. The average size of own land holding was slightly higher in B/P (1.95 ha) than M/C (1.39 ha) and N/R (1.54 ha). The study revealed that, the average size of total own land holding was $1.32 \mathrm{ha}$, which is greater than the national average size of land holding 0.83 ha (MoAD, 2013).

\section{II) LAND USE ARRANGEMENT}

By the surveyed farmers most of the area cultivated was under TPR (58.63 ha) as compared to DDSR (27.62 ha). This is because most of the farmers in all clusters preferred TPR under irrigated condition and DDSR under less irrigated condition. Unirrigated medium land and rainfed lowland condition due to shortage of water. Pandey and Velasco (1999) also reported higher adaptation of DSR by smallholder farmers mainly under unirrigated condition. Mann et al. (2006) reported that the rice in Punjab province in India has recently 
expanded to 0.65 million hectares of non-traditional belt, where puddling is not much practiced due to severe shortage of water.

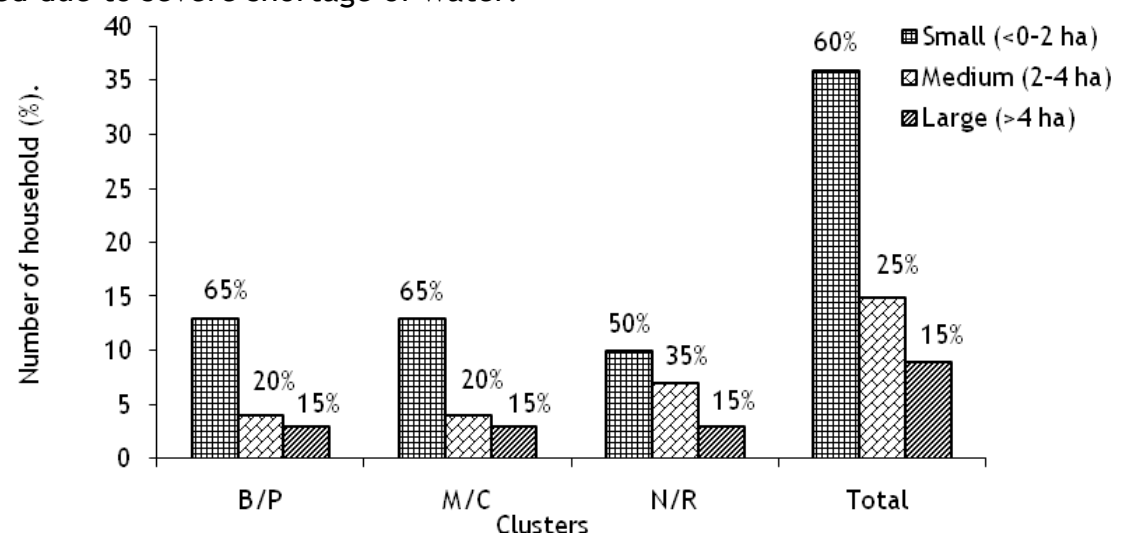

Figure 3. Distribution of land landholding by clusters of the field survey in Bara/Parsa (B/P), Makwanpur/ Chitwan (M/C), and Nawalparasi/Rupandehi (N/R) districts in 2010

\section{III) CROPPING SYSTEM}

Rice-wheat was the pre dominant cropping system in surveyed area. In total, this was followed by Rice- fallow- maize, Rice-fallow-fallow and Rice-lentil-maize cropping system. Rice-wheat was followed by Rice-lentil-maize in B/P, Rice-wheat-maize and Rice-fallowmaize in $M / C$, and Rice-fallow-maize in N/R (Table 1). The dominant rice based cropping system might be due to food habit of Nepalese farmers and tradition. Rice meets more than $50 \%$ of the total calories requirement of the Nepalese people (NARC, 2007).

\section{IV) ADOPTION OF DDSR BY FARMERS}

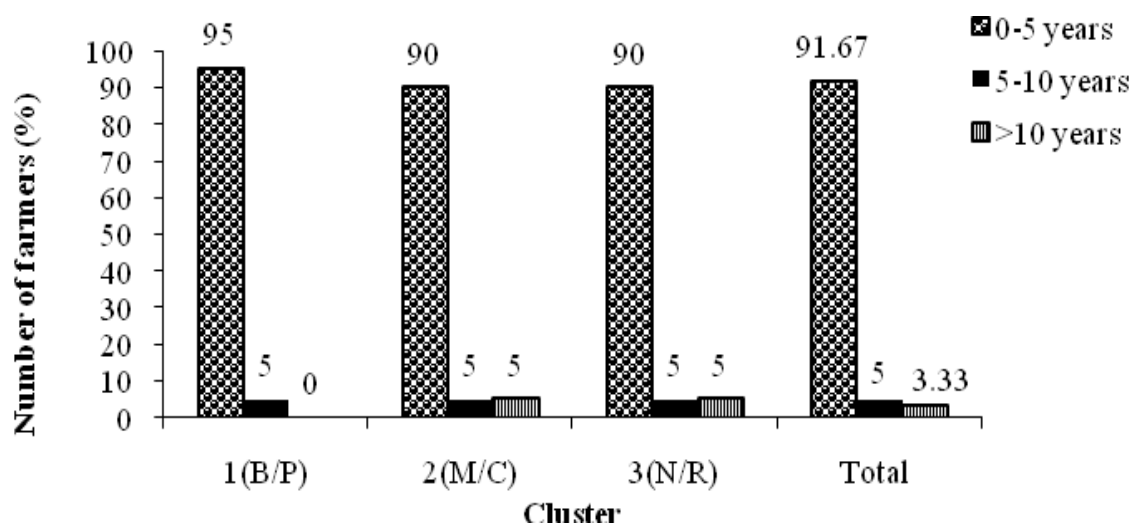

Figure 4. Adoption of DDSR by cluster in Bara/ Parsa (B/P), Makwanpur/ Chitwan (M/C), and

Nawalparasi/ Rupandehi (N/R) districts in 2010

$-106-$ 
Since 5 years the number of DDSR grower is increasing rapidly in all clusters (Figure 4). In $\mathrm{B} / \mathrm{P}, 95 \%$ farmers were new comers, while $5 \%$ adopted DDSR since 5-10 years. Similarly, in $M / C$ and N/R, $90 \%$ farmers adopted DSR since $0-5$ years, $5 \%$ of the farmers were adopted since 5-10 years and remaining 5\% growers adopted this method of cultivation since more than 10 years. Dry-seeded rice is a traditional practice developed by farmers to suit the agro-ecological conditions in systems ranging from shifting cultivation in the humid forest zones to intensive cultivation in the rainfed lowlands (Johnson et al., 1991; My et al., 1995) in Asia, Africa, and Central and South America. In India, dry-seeding is extensively practiced in rainfed lowlands, uplands, and flood-prone areas, while wet-seeding remains a common practice in irrigated areas (Misra et al., 2005).

\section{V) WILLINGNESS TO ADOPT DRY DIRECT SEEDED RICE}

The result showed high willingness of farmers to adopt DDSR in cluster regions. Generally, $95 \%$ farmers in N/R, $90 \%$ farmers in $B / P$ and $85 \%$ farmers in $M / C$ under study will continue to practice DDSR in next year. In general $90 \%$ farmers will adopt DDSR in next year (Figure 5). The high willingness of adoption of this method could be due to advantages of reduced labor requirements and drudgery, earlier crop maturity, more efficient water use and higher tolerance of water deficit, and often higher profit in areas with an assured water supply (Balasubramanian and Hill, 2002).

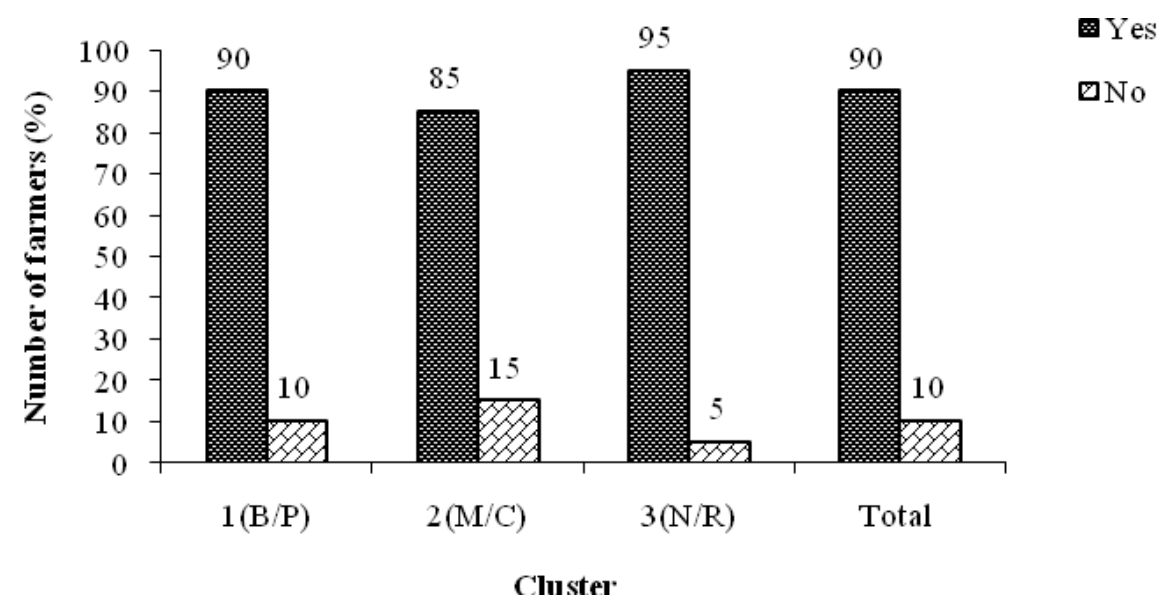

Figure 5. Willingness of farmers adopting DSR in next year by cluster in Bara/ Parsa (B/P), Makwanpur / Chitwan (M/C), and Nawal parasi/Rupandehi (N/R) districts in 2010

\section{VI) PERCEPTION OF FARMERS ON MERITS AND DEMERITS OF DDSR and TPR}

Rank order index showed that low cost of cultivation was the strength of DDSR followed by less irrigation requirement (Table 1), while farmers ranked increased weed infestation, 
poor crop establishment, and reduced grain and straw yield in DDSR as the major problems (Table 2). Famers ranked less weed infestation, and better crop establishment in TPR as the major advantage over DDSR (Table 3). High cost of cultivation, higher irrigation requirement in puddling, and deterioration of soil physical properties due to puddling were the major problems of TPR ranked by farmers (Table 4). In a study of farmer's perceptions on DSR, benefits perceived by farmers included increased cropping intensity and productivity, the efficient use of early season rainfall and available soil nitrate, reduced water use (700-900 mm rainfall per crop), and lower risk of drought at maturity (Rao and Moody, 1994).

Table 1. Rank order index for merits of direct seeded rice by clusters of the field survey in Bara/Parsa, Makwanpur/Chitwan, and Nawalparasi/Rupandehi districts in 2010

\begin{tabular}{|c|c|c|c|c|c|c|c|c|}
\hline \multirow[t]{2}{*}{ S.N. } & \multirow{2}{*}{$\begin{array}{l}\text { Cluster } \\
\text { Merits }\end{array}$} & \multicolumn{2}{|c|}{$\begin{array}{l}\text { Bara/ } \\
\text { Parsa }\end{array}$} & \multicolumn{2}{|c|}{$\begin{array}{l}\text { Makwanpur/ } \\
\text { Chitwan }\end{array}$} & \multicolumn{2}{|c|}{$\begin{array}{l}\text { Nawalparasi/ } \\
\text { Rupandehi }\end{array}$} & \multirow{2}{*}{$\begin{array}{c}\text { Total } \\
\text { Index Rank }\end{array}$} \\
\hline & & Index & Rank & Index & Rank & Index & Rank & \\
\hline 1 & Reduced cost of cultivation & 0.95 & $\mathrm{I}$ & 0.91 & I & 0.90 & $\mathrm{I}$ & $0.92 \quad 1$ \\
\hline 2 & Less irrigation requirement & 0.57 & II & 0.58 & II & 0.65 & II & 0.61 \\
\hline 3 & $\begin{array}{l}\text { Increased fertilizer } \\
\text { efficiency }\end{array}$ & 0.31 & IV & 0.35 & IV & 0.43 & III & 0.36 \\
\hline 4 & Timely crop establishment & 0.30 & V & 0.33 & $\mathrm{~V}$ & 0.37 & V & $0.33 \mathrm{~V}$ \\
\hline 5 & $\begin{array}{l}\text { Increased soil health } \\
\text { condition }\end{array}$ & 0.48 & III & 0.46 & III & 0.38 & IV & $0.44 \quad \mathrm{III}$ \\
\hline
\end{tabular}

Table 2. Rank order index for demerits of direct seeded rice by clusters of the field survey in Bara/Parsa, Makwanpur/Chitwan, and Nawalparasi/Rupandehi districts in 2010

\begin{tabular}{|c|c|c|c|c|c|c|c|c|c|}
\hline \multirow[t]{2}{*}{ S.N. } & \multirow{2}{*}{$\begin{array}{c}\text { Cluster } \\
\text { Demerits }\end{array}$} & \multicolumn{2}{|c|}{ Bara/ Parsa } & \multicolumn{2}{|c|}{$\begin{array}{c}\text { Makwanpur/ } \\
\text { Chitwan }\end{array}$} & \multicolumn{2}{|c|}{$\begin{array}{l}\text { Nawalparasi/ } \\
\text { Rupandehi }\end{array}$} & \multicolumn{2}{|c|}{ Total } \\
\hline & & Index & Rank & Index & Rank & Index & Rank & Index & Rank \\
\hline 1 & Increased weed infestation & 0.95 & I & 0.97 & 1 & 0.97 & $\mathrm{I}$ & 0.96 & $\mathrm{I}$ \\
\hline 2 & Reduced grain and straw yield & 0.51 & III & 0.48 & III & 0.53 & III & 0.51 & III \\
\hline 3 & Increased disease infestation & 0.35 & IV & 0.33 & IV & 0.33 & IV & 0.34 & IV \\
\hline 4 & Poor crop establishment & 0.62 & II & 0.67 & II & 0.58 & II & 0.62 & II \\
\hline 5 & Difficult to fertilizer management & 0.05 & V & 0.02 & V & 0.06 & V & 0.04 & V \\
\hline
\end{tabular}

Table 3. Rank order index for merits of transplanted rice by clusters of the field survey in Bara/Parsa, Makwanpur/Chitwan, and Nawalparasi/Rupandehi districts in 2010

\begin{tabular}{llllllllll}
\hline \multirow{2}{*}{ S.N. } & \multirow{2}{*}{ Cluster } & \multicolumn{2}{c}{$\begin{array}{c}\text { Bara/ } \\
\text { Parsa }\end{array}$} & \multicolumn{2}{c}{$\begin{array}{c}\text { Makwanpur/ } \\
\text { Chitwan }\end{array}$} & \multicolumn{2}{c}{$\begin{array}{c}\text { Nawalparasi/ } \\
\text { Rupandehi }\end{array}$} & \multirow{2}{*}{ Total } \\
\cline { 2 - 10 } & \multicolumn{1}{c}{ Merits } & Index Rank & Index & Rank & Index & Rank & Index Rank \\
\hline 1 & Increased grain and straw yield & 0.50 & II & 0.31 & V & 0.28 & V & 0.36 & IV \\
2 & Water stagnation & 0.38 & IV & 0.40 & III & 0.46 & III & 0.41 & III \\
\hline
\end{tabular}

$-108-$ 


\begin{tabular}{lllllllllll}
\hline 3 & Less weed infestation & 0.85 & I & 0.88 & I & 0.93 & I & 0.89 & I \\
4 & Less disease and pest infestation & 0.30 & V & 0.32 & IV & 0.31 & IV & 0.31 & V \\
5 & Better crop establishment & 0.42 & III & 0.57 & II & 0.50 & II & 0.50 & II \\
\hline
\end{tabular}

Table 4. Rank order index for demerits of transplanted rice by clusters of the field survey in Bara/Parsa, Makwanpur/Chitwan, and Nawalparasi/Rupandehi districts in 2010

\begin{tabular}{lllllllllll}
\hline \multirow{2}{*}{ S.N. } & \multicolumn{2}{c}{ Cluster } & \multicolumn{2}{c}{ Bara/ Parsa } & \multicolumn{2}{c}{$\begin{array}{c}\text { Makwanpur/ } \\
\text { Chitwan }\end{array}$} & $\begin{array}{c}\text { Nawalparasi/ } \\
\text { Rupandehi }\end{array}$ & Total \\
\cline { 2 - 12 } & \multicolumn{1}{c}{ Demerits } & Index & Rank & Index & Rank & Index & Rank & Index & Rank \\
\hline 1 & High cost of cultivation & 0.9 & I & 0.887 & I & 0.875 & I & 0.887 & I \\
2 & High irrigation requirement & 0.75 & II & 0.737 & II & 0.725 & II & 0.737 & II \\
3 & Deteriorates soil & 0.55 & III & 0.587 & III & 0.6 & III & 0.579 & III \\
4 & Delay harvesting & 0.225 & IV & 0.225 & IV & 0.237 & IV & 0.204 & IV \\
5 & Low fertilization efficiency & 0.075 & V & 0.062 & V & 0.062 & V & 0.066 & V \\
\hline
\end{tabular}

\section{VII) ECONOMICS OF PRODUCTION}

Transplanted rice required more cost to cultivate as compared to direct seeded rice. Net return per hectare was higher in DDSR than in TPR in all clusters (Table 5). On an average $\mathrm{B}: \mathrm{C}$ ratio was higher in the DDSR (2.00) as compared to the TPR (1.63). Labour saving and low irrigation requirement were the major components contributed for low cost of cultivation, and higher farm-gate price of paddy at earlier harvest of DDSR were the main reasons for this profitability as compared to TPR. Sah (2006) observed low cost DDSR technologies in farmer's field, and concluded that DDSR was superior to farmers practice (TPR). Several researches showed that, DDSR can reduce up to $50 \%$ labor requirements for rice cultivation (Singh et al., 1994). Direct seeding reduced labor wages about US \$29-36 compared with transplanted rice (\$177-183) (Rashid et al., 2009), and DDSR required 13\% less irrigation water than TPR. This was due to the lower amount of water applied during land preparation.

Table 5. Benefit and cost analysis of DDSR and TPR by clusters of the field survey in Bara/Parsa, Makwanpur/Chitwan, and Nawalparasi/Rupandehi districts in 2010

\begin{tabular}{|c|c|c|c|c|c|c|c|c|}
\hline \multirow[t]{2}{*}{ Particulars } & \multicolumn{2}{|c|}{ Bara/ Parsa } & \multicolumn{2}{|c|}{$\begin{array}{c}\text { Makwanpur/ } \\
\text { Chitwan }\end{array}$} & \multicolumn{2}{|c|}{$\begin{array}{l}\text { Nawalparasi/ } \\
\text { Rupandehi }\end{array}$} & \multicolumn{2}{|c|}{ Total } \\
\hline & DSR & TPR & DSR & TPR & DSR & TPR & DSR & TPR \\
\hline Cost of cultivation (Rs.,000)/ha & 49.10 & 64.40 & 54.04 & 71.34 & 53.93 & 70.23 & 52.53 & 68.65 \\
\hline Gross return ha-1 (Rs.,000) & 99.05 & 102.95 & 114.13 & 124.13 & 101.07 & 109.57 & 104.75 & 112.22 \\
\hline Net benefit ha ${ }^{-1}$ (Rs.,000) & 49.95 & 38.55 & 60.09 & 52.79 & 47.13 & 39.33 & 39.29 & 32.66 \\
\hline $\mathrm{B}: \mathrm{C}$ ratio & 2.02 & 1.59 & 2.11 & 1.74 & 1.87 & 1.56 & 2.00 & 1.63 \\
\hline
\end{tabular}

Note: DSR- direct seeded rice, TPR- transplanted rice 


\section{CONCLUSION}

Increased weed infestation, poor crop establishment and reduced grain yield were major constraints of DDSR, whereas high cost of cultivation and higher water requirement were major constraints of TPR. In spite of realizing the lower yield in DDSR as compared to TPR, the net benefit and B:C ratio were higher in DDSR because of lower cost of cultivation as compared to TPR. Thus DDSR is preferred for better return, less irrigation requirement, low cost of cultivation, and less drudgery.

\section{ACKNOWLEDGEMENT}

We are grateful to the International Maize and Wheat Improvement Center (CIMMYT) for providing financial support for this study; Cereal System Initiative for South Asia (CSISA) for providing valuable advice, help and technical support, particularly for selecting the research tools and household study.

\section{REFERENCES}

Balasubramanian, V., and J. Hill. 2002. Direct seeding of rice in Asia: emerging issues and strategic research needs for the 21st century. In: S. P. Pandey et al (eds.) Direct seeding: research strategies and opportunities. Los Banos, Philippines. International Rice Research Institute. pp. 15-39.

Gopal, R., R. K. Jat, R. K. Malik, V. Kumar, M. M. Alam, M. L. Jat, M. A. Mazid, Y. S. Sahrawat, A. Mc. Donald, and R. Gupta. 2010. Direct dry seeded rice production technology and weed management in rice based systems. Technical bulletin. International Maize and Wheat Improvement Center. New Delhi. India. 28p.

Johnson, D. E., Lee, P. G., and Wilman, D. (1991). Experiments with upland rice in southern Belize: Fertilizer application, weed control, plant spacing, sowing rate and variety. J. Agric. Sci. Cambridge 116, 201-215. Available on: http://www.nri.org/ work/weedsricepoor.pdf. [Retrieved on 22 December 2010]

Mann, R. A., M. Munir, and M. A. Haqqani. 2007. Effect of resource conservation techniques on crop productivity in rice-wheat cropping system. Pakistan J. Agric. 18: 76-82.

Miah, A. Q. 1993. Applied statistics. A course handbook for human settlements planning, determination of sample size.division of human settlement development, Asian Institute of Technology, Thiland. 303p.

Misra, B., L. V. Subba Rao, and S. V. Subbaiah. 2005. Rice varieties for direct-seeding. In: Y. Singh, G. Singh, V. P. Singh, P. Singh, B. Hardy, D. E. Johnson, and M. Mortimer (eds.) “'Direct-Seeding of Rice and Weed Management in the Irrigated Rice-Wheat Cropping System of the Indo Gangetic Plains'. Directorate of Experiment Station, G.B. Pant University of Agriculture and Technology, Pantnagar, India. 10p.

MoAD. 20012/13. Statistical information on Nepalese agriculture (2012/13). Agribusiness Promotion and Statistics Division, Singh Darbar, Kathmandu.

$-110-$ 
My, T. V., T. P. Tuong, V. T. Xuan, and N. T. Nghiep. 1995. Dry seeding rice for increased cropping intensity in Long An Province, Vietnam. In: G. L. Denning, and V. T. Xuan (eds.) Vietnam and IRRI, a partnership in rice research. Vietnam and Ministry of Agriculture and Food Industry and Makati (Philippines), International Rice Research Institute. pp. 111-122.

NARC. 2007. Research highlights: 2002/03-2006/07. Communication, Publication and Documentation Division, Nepal Agricultural Research Council (NARC), Khumaltar, Lalitpur. 17p.

Palis, F. G., G. R. Singleton, M. C. Casimero, and B. Hardy. 2010. Research to impact: case studies for natural resource management for irrigated rice in Asia. International Rice Research Institute, Los Banos, Philippines. 370p.

Pandey, S., and L. Velasco. 1999. Economics of alternative rice establishment methods in Asia: a strategic analysis. Social Sciences Division Discussion Paper, International Rice Research Institute, Los Banos, Philippines.

Rao, A. N. 2010. Integrated Weed Management in Rice in India. Rice Knowledge Management Portal (RKMP). International Rice Research Institute (IRRI). 1p.

Rao, A. N., and K. Moody. 1994. Ecology and management of weeds in farmers' direct-seeded rice (Oryza sativa L.) fields. Consultancy report of work done from 1 July to 31 December 1994. International Rice Research Institute, Los Banos, Philippines. 81p.

Rashid, M. H., M. M. Alam, M. A. Hossain Khan, J. K. Ladha. 2009. Productivity and resource use of direct-(drum)-seeded and transplanted rice in puddled soils in rice-rice and rice-wheat ecosystems. Field Crops Research. 113: 274-281.

Sah, G. 2006. Direct Seeded Rice: A low cost establishment technology. Rice fact sheet, International Rice Research Institute, Las Banos, Phillipines.

Singh, S., R. K. Sharma, G. Singh, S. S. Singh, U. P. Singh, M. S. Gill, M. L. Jat, S. K. Sharma, R. K. Malik, A. Joshi, S. G. Patil, J. K. Ladha, and R. Gupta. 2005. Direct Seeded Rice: A Promising Resource Conserving Technology. Rice-Wheat Consortium for Indo-Gangetic Plains. NASC Complex, Pusa, New Delhi. pp.11-12.

Yadav, D. S., A. M. Sushant, Mortimer, and D. E. Johnson. 2004. Studies on direct seeding of rice, weed control, and tillage practices in the rice- wheat cropping system in eastern uttar Pradesh. Indian Journal of Agronomy. 44 (6). 23-26. 